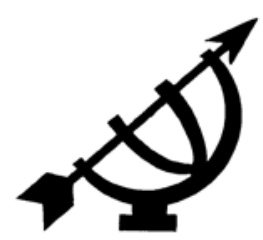

\title{
Institutional statism: an overview of the formulation of the taxi recapitalisation policy
}

D. van Schalkwyk

Department of Political Studies

Potchefstroom Campus

North-West University

POTCHEFSTROOM

E-mail: dvschalkwyk@pgwc.gov.za

\section{Abstract \\ Institutional statism: an overview of the formulation of the taxi recapitalisation policy}

This article provides an overview of the government's formulation of the taxi recapitalisation policy which is aimed at regulating the minibus taxi industry. Coupled with a brief social and politico-historical context of the policy, the aim is to highlight the government's statist conduct in the formulation of the recapitalisation policy. The minibus taxi industry started to fulfil a prominent role in the 1970s as a result of a loophole in the legislation of the former apartheid government. It is currently the most accessible mode of public transport and conveys 65 per cent of the country's commuters daily. Consequently, the Industry is an imperative force to be considered by the government in its formulation of transport policies. However, the industry is characterised by numerous problems, including a high rate of minibus taxis involved in accidents, unroadworthy vehicles and violence. It is in this context that the government formulated both the original and revised versions of the recapitalisation policy. However, the formulation of the policy has been problematic. The government followed a statist approach during the formulation process when it directed the course of the process according to its interests and without adequate consultation with relevant role players. 


\section{Opsomming}

\section{Institusialisme: 'n oorsig van die formulering van die taxiherkapitaliseringsbeleid}

Hierdie artikel verskaf 'n oorsig hoe die Suid-Afrikaanse regering die taxiherkapitaliseringsbeleid geformuleer het. Die regering beoog om met behulp van die herkapitaliseringsbeleid die land se minibus taxibedryf te reguleer. Die doel van die artikel is om, tesame met 'n kort oorsig van die sosiale en polities-historiese konteks van die beleid, te beklemtoon hoe die regering 'n sogenaamde benadering van institusialisme tydens die formulering van die herkapitaliseringsbeleid gevolg het. Die minibus taxibedryf vervul sedert die sewentigerjare 'n belangrike rol as gevolg van 'n skuiwergat in die wetgewing van die voormalige apartheidsregering. Dit is tans die toeganklikste vorm van openbare vervoer met 65 persent van die land se pendelaars wat verkies om met minibus taxi's te pendel. Dit is dus belangrik dat die regering die bedryf in ag neem indien beleide gerig op die openbare vervoerstelsel geformuleer word. Die bedryf word egter deur verskeie probleme in die gesig gestaar. Probleme sluit onder andere 'n hoë ongeluksyfer, onpadwaardige voertuie en geweld in. Die regering het, in 'n poging om hierdie probleme in die bedryf te hanteer, sowel die oorspronklike en hersiene weergawes van die herkapitaliseringsbeleid geformuleer. Hierdie formuleringsproses het egter nie sonder probleme verloop nie aangesien die regering 'n tipiese benadering van institutialisme gevolg het. Die regering het byvoorbeeld sy eie belange voorop gestel en versuim om die relevante rolspelers by die proses te betrek of voldoende te raadpleeg.

\section{Introduction}

One of the underlying assumptions of the policymaking process is the promotion of the general welfare and conditions of society as a whole, or at least a certain sector within that society. Policy theorists such as Anderson (2006) refers to the process as a definite plan of action; a plan of action that the government of the day enforces in order to ascertain a way to allocate scarce resources to improve the circumstances of its constituency. The formulation stage forms part of this policymaking process. When an issue in society is regarded as a policy problem and attains policy agenda status, the government reacts by formulating a policy response to attend to the perceived policy problem. ${ }^{1}$ The question that guides this article is to

1 For Anderson (2006:82) a policy problem is a condition or situation that produces needs and dissatisfaction on the part of people for which relief or 
what extent did the government exemplified statist conduct in its formulation of the taxi recapitalisation policy by utilising institutional statism as a theoretical framework. 2 The aim is to emphasise that inadequate consultation with the public relating to various aspects of a specific policy could threaten the potential success of such a policy, making the policymaking process, and more specifically the formulation stage, a futile exercise. ${ }^{3}$ The first part of the article draws attention to the rationale for using institutional statism to analyse the formulation of the recapitalisation policy by providing the theoretical framework that anchors this article. In the second part the article provides the social and politico-historical context of the recapitalisation policy by providing a brief historical development of the South African minibus taxi industry. The former justifies why the government decided to formulate the recapitalisation policy. The final section focuses on specific examples highlighting some of the instances where the government explicitly demonstrated a statist approach in the formulation of the recapitalisation policy. This is done in the light of the theoretical underpinnings as developed in the first part.

\section{Background and rationale for institutional statism theory}

Before turning to a discussion of the institutional statism theory in relation to the themes of this article, it is necessary to pay attention to the role and functions of political (i.e. public policy) institutions. Institutions are the arena within which the policymaking process occurs, as they process inputs from society and turn them into outputs (public policies). John (2000:38) notes that institutions define how a political system operates. Likewise, Dye (2005:12) argues that the relationship between public policy and government institutions is very close since a policy does not becomes a public policy until it has passed through the policymaking process stages, which

redress is sought. The government is generally responsible for the facilitation of the so-called relief or redress. statism.

According to John (2000:204), formulation is normally viewed as the most critical step in the policymaking process since such a policy presumably attends to the interests, needs and demands of society, coupled with that of the government. Therefore, everyone is constantly influenced by the policies of the government as it has important consequences for the whole of society. 
is enforced by some government institutions (e.g. legislature, executive). De Coning and Cloete (2006:39) support this notion when they state that the premise of the institutional statism approach is that the policymaking process is the product of public institutions, which are responsible for its formulation.

Institutional statism is a theoretical confluence of some elements of elite and public choice theory (March \& Olsen, 1997:139). As a variant of elite theory, it acknowledges that elites may assemble in the institutions of the government, influencing the policymaking process in accordance with their particular needs and interests. As the government is the core arena where public policy is formulated and where politics happens - it, together with its policy institutions, becomes a determinant of policy formulation. In this way, the government turns out to be dominant in political life. This domination is illustrated in the government feeding policy inputs and prescriptions to sections of society (elites), who in turn reinforces the state's legitimacy (public choice) and capacity to react to those problems via the policymaking process.

By directing the course of the policymaking process, government institutions provide public policies with three distinctive characteristics (Dye, 2005:12). Firstly, they afford legitimacy to policies, projecting legal obligations into the policies that are made. Government policies (e.g. the recapitalisation policy) command the loyalty of the country's citizens (e.g. roleplayers in the minibus taxi industry) and are generally regarded as legally binding on citizens. For instance, although people may view the policies of other groups in society churches, schools and so forth - as important and even binding, these policies do not, as with government policies, involve legal obligations. For example, government's legislation on common law issues such as theft states that one could go to jail for stealing, and is thus legally binding. On the other hand, a school's policy might state that one should not be late, but the punctuality policy is not legally binding on all of society.

Secondly, the policies of government are universal. As a result, these public policies are applicable to all citizens. In contrast to this, the policies of other groups only reach a part within society. For example, the legislation on theft is binding on all citizens, whereas the no late-coming to school policy is only applicable to the learners of a specific school. Thirdly, the government monopolises coercion in society. In the public policy domain this means that the government is the only institution that can legitimately sanction violators of its public policies. The sanctions that can be imposed by other 
groups in society are more limited: for example, one would most probably only be summoned to do detention if one arrives late at school, while one could go to jail for theft.

Lastly, any discussion on the policymaking process and a particular theoretical discourse being utilised to analyse this process, should consider the policy environment. The reason for this is that a policy such as the recapitalisation policy does not transpire within a vacuum, but within a specific, often highly dynamic, policy environment. Therefore, the government and its policyformulators are greatly influenced by this environment since it generates the actions that they can take (Hill, 1980:103; Palumbo \& Calista, 1990:5; and Anderson, 2006:39). Policyformulators thus need to consider the policy environment and bear in mind important environmental factors such as the socio-economic conditions of the target population of a particular policy. In an attempt to grasp the features of the policy environment, policyformulators need to take into account the input from various policy entrepreneurs in society. 4 To put it differently, all role players have to bargain during the process and the target population is one of these role players. Authors such as Larsen, Taylor-Gooby and Kananen (2006:631) underline this when they comment that the government should "... ensure that all affected groups are consulted, and, secondly, actively engage [them] in the formulation of a policy".

\section{Social and politico-historical context of the taxi recapitalisation policy}

The context from which the need as well as the reaction to a specific policy originates is often referred to as the policy environment. As mentioned above, the formulation of a policy such as the recapitalisation policy does not occur in a political or social vacuum. Therefore, it is the aim of this section to provide a brief social and politico-historical context from which the recapitalisation policy evolved (i.e. the policy environment) in terms of a brief overview of the development of the industry.

4 Citizens, government agency officials, representatives of interest groups and so forth, who through effort, persistence, and/or expenditure of resources promote action on public policy issues, are often referred to as policyentrepreneurs (John, 2000:204; Theodoulo \& Kofinis, 2004:137; and Anderson, 2006:92, 316). Often these entrepreneurs in fact identify policyproblems, determine what should be discussed during policydebates and gather support for specific policyproposals. 
The industry was conceived during the 1970s based on a loophole in the Road Transportation Act of 1977 of the former apartheid government's transport legislation. The loophole in this Act was that it did not define - or, indeed, even mention - the word taxi. It referred only to buses and cars. 5 This made it possible for minibus taxis to redefine their capacity to nine passengers, including the driver. 6 Therefore, minibuses could avoid the regulations applicable to both buses and cars by leaving a number of seats empty, carrying only eight passengers. By following this approach, they were, strictly speaking, not operating as either a car (less than eight), sedan taxi (four plus one) or a bus (more than eight), and could not therefore be judged in those terms. Since then, despite regulation and deregulation attempts by both the apartheid (1977-1994) and democratic governments (1994-current) the industry has grew into the most accessible mode of public transport in the country and proved to be an essential segment of the country's urban transport sector.

It is estimated that $38 \%$ of the total South African population are dependent on public transport on a daily basis, and that the majority of the working population (65\%) use minibus taxis. In comparison, only $21 \%$ use buses, while $14 \%$ use trains. In addition, the National Household Transport Survey of 2003 found that $75,7 \%$ and $37,7 \%$ of South African citizens do not have access to train and bus services respectively. In contrast to this, only $8,6 \%$ of the citizens indicated that they do not have access to a minibus taxi service (SADT, 2007a). Furthermore, South African workers walk approximately seventeen minutes to a train station, nine minutes to a bus stop and eight minutes to a minibus loading place. In its development of a national scholar transport policy the Department of Transport (SADT, 2007b:6) also found that the highest proportion of trips to school by public transport are made by minibus taxi. It is therefore evident that South Africans have easier access to minibus taxi services in comparison with any other form of public transport.

Despite the above, the industry, with its most prominent role players being the taxi owners, taxi drivers, taxi associations, vehicle cleaners, fare collectors and taxi rank marshals, does not receive an

5 A bus was defined as a vehicle that could transport more than eight passengers, while a car was described as a vehicle carrying up to eight passengers (SADT, 1977:5-6).

6 This phenomenon of minibus taxis carrying eight passengers plus the driver soon became commonly known as the " $8+1$ " vehicle. 
official subsidy from the government. Also, the industry has since its inception been characterised by perceived problems, including a high rate of minibus taxis involved in accidents, coupled with unroadworthy vehicles and violence. In an effort to establish sustainable solutions to these perceived problems, the government created the National Taxi Task Team with the co-operation of role players within the industry. The Task Team was responsible for investigating the issues and problems in the industry and providing solutions. After 36 public hearings throughout South Africa between August 1995 and January 1996, the Task Team submitted a 300page final report to the minister of transport (National Taxi Task Team, 1996:6; Dugard, 2001:144; and Barrett, 2003:14).

The concept of the recapitalisation of the South African minibus taxi industry can be traced back to the third recommendation of the above-mentioned Task Team. This recommendation encourages the implementation of policies (i.e. the recapitalisation policy) that would empower the minibus taxi industry economically and formalise it (National Taxi Task Team, 1996:114). Other recommendations included the regulation and enhanced control of the industry by establishing a National Minibus Taxi Association as well as the establishment of minimum labour standards (National Taxi Task Team, $1996: 59,103)$. It is in this context that the government announced the original taxi recapitalisation policy in 1999, which was replaced by the revised version of the policy in 2004 .

\section{Elements/aspects of the taxi recapitalisation policy}

The government accepted the recommendations of the National Taxi Task Team in 1998 and announced the original recapitalisation policy (with a R4,4 billion budget) in September 1999 but after some financial and operational concerns, it announced the revised recapitalisation policy (with a R7,7 billion budget) in November 2004. The most significant legislation concerning the recapitalisation policy includes the National Land Transport Transition Act of 2000, the National Land Transport Transition Amendment Act of 2006 and the National Land Transport Bill of 2008. In these legislations the recapitalisation policy is described as an attempt to formalise, regulate, and economically empower the South African minibus taxi industry through the replacement of the country's current minibus taxi fleet with newer, bigger and safer vehicles. In addition, owners will receive a scrapping allowance (i.e. R50 000) as a refund when they submit their old minibus taxis, which they can utilise to purchase a new minibus taxi or to exit the industry (SA, 2000:44; Parliamentary 
Monitoring Group, 2000; SA, 2006:16; SADT, 2008:5, 15; and SA, 2008:44). Both the original and revised recapitalisation policies were also designed to attend to the above-mentioned perceived problems in the South African minibus taxi industry.

In its formulation of the recapitalisation policy the government has set various goals. 7 According to its taxi recapitalisation policy document, the Department of Transport (SADT, 2008:5) lists these goals as follows:

- The minibus taxi industry will move into the formal political economy by paying taxes on their income.

- The establishment of minibus taxi co-operatives will assist operators to purchase both vehicle parts and diesel at lower prices.

- The working conditions of everyone involved in the minibus taxi industry will improve.

- The proposed vehicles will be safer, more reliable and comfortable for both the drivers and commuters.

- The operating patterns of the new taxi vehicle (NTV) will be more easily accessible as well as controllable.

- Black economic empowerment will be encouraged.

- Taxi wars, especially for the right to use lucrative routes and minibus taxi ranks, will be halted.

- The largest part of South Africa's urban transport system will be revitalised.

In addition, the following are according to the taxi recapitalisation policy document of the Department of Transport (SADT, 2008:5) the objectives $^{8}$ of the recapitalisation policy:

- Effective black economic empowerment of the minibus taxi industry through the establishment of minibus taxi co-operatives

7 According to Roux (2006:128) a goal is "an unrealised state not yet achieved by the members of an organisation but which they regard as desirable".

8 An objective is described by Roux (2006:128) as "a short term goal that can be deducted from an organisation's mission and that could be stated by means of a process of negotiation". 
- The introduction of a once-off scrapping allowance of R50 000 per scrapped vehicle to legal operators with registered minibus taxi vehicles

- Effective law enforcement in the minibus taxi industry

- The introduction of new vehicles with specific safety specifications

- Sustainable formalisation, regulation and registration of the minibus taxi industry in order to prepare the industry adequately for the implementation of the policy

The official target population of the recapitalisation policy is the taxi owners, while the official role players are the following:

- National governmental departments coupled with their provincial counterparts, including the Departments of Transport, Trade and Industry, Minerals and Energy, Environmental Affairs and Tourism, Labour, and Finance

- The South African National Standards, previously known as the South African Bureau for Standards

- The motor industry

- The South African National Taxi Council (Santaco) ${ }^{9}$ (SADT, 2008:22-25.)

\section{Institutional statism and the formulation of the taxi recapitalisation policy}

\subsection{Identifying the target population and problem in the minibus taxi industry}

As mentioned above the taxi owners were identified as the official target population of the recapitalisation policy by the government.

9 The government has always only acknowledged one national minibus taxi association (i.e. Santaco, 2004) as an official role player in the recapitalisation policy. Relating to the original version of the policy, the government commented, "Government continues to recognise only, Santaco as the only [role] player in the [minibus taxi] industry" (Mabuza, 2003:2). As regards the revised recapitalisation policy, in the words of Montana (2005): "We talk to everyone [in the minibus taxi industry]. The provincial ministers of transport consulted with everyone in all the provinces. However, Santaco is the ultimate and legitimate voice of the [South African minibus] taxi industry". 
The government did this without consulting the industry, making the process a flawed one. Identifying only the taxi owners as the official target population of the recapitalisation policy is testament to the short-sightedness of the government in the formulation of the recapitalisation policy. This article argues that other relevant role players in the South African minibus taxi industry - such as taxi drivers, vehicle washers, fare collectors, rank marshals - should all be included in the official target population of the recapitalisation policy, since the policy has the potential to influence the socio-economic circumstances of all these role players, not only the official target group (i.e. taxi owners).

Ideally, the policymaking process for policies (e.g. the recapitalisation policy) should start with the identification of a policyproblem. The implication is that a particular issue is regarded as a public problem and needs to be dealt with. Such a phenomenon is thus viewed as unacceptable and therefore appropriate for the government to act on. To quote Fourie (2004:11): "If there were nothing to solve, policy responses would not be necessary." For example, if the South African government were not convinced that there is a problem within the minibus taxi industry, a policy response such as the recapitalisation policy would not have been initiated in the first place.

The government thus identified a policyproblem and decided to react (i.e. a policyresponse). Often in democratic societies such as South Africa a policyproblem is also identified and/or emerges from civil society who then request the government to formulate a policy in accordance with how they see the problem (Dye, 2005:31). However, this was not the case in terms of the recapitalisation policy. From the beginning there has been an ambivalent recognition of the policyproblem between the government and the minibus taxi industry. Certain issues relating to the industry are interpreted in noticeably different ways by the government as opposed to the industry's role players.

With regard to the accident rate and unroadworthy vehicles, the industry never saw a problem and consequently did not demand a policyresponse from the government. Therefore, there was a difference in the identification of the problem as well as an absence of mutual recognition. 10 For example, in a document presented to the

10 Parsons (1997:87) observes that the public policymaking process should entails the mutual recognition of a problem as a policyproblem. 
government to raise their concerns with the original recapitalisation policy, Top Six (2000:4) and its members argued that "... the country's current fleet of minibus taxis are safe and not un-roadworthy as government suggest and it therefore cannot be blamed for accidents on the country's roads". In addition, three years later, Top Six were persisting with this view, noting, "We are happy with the present fleet of vehicles" (Khangale, 2003:2). Also, a month before the official launch of the implementation of the revised TRP in October 2006, Santaco, the KwaZulu-Natal Transport Alliance, and the Western Cape Taxi Association "pointed out that government's claim that the taxi fleets were all either ageing or un-roadworthy was misleading". These organisations made this point at a presentation on the recapitalisation policy before the government's Transport Portfolio Committee (Parliamentary Monitoring Group, 2006).

However, on the other hand, the industry also recognises the prevalence of violence as a problem in the South African minibus taxi industry. For instance, and as mentioned above, minibus taxi violence was one of the reasons why the industry together with the government established the National Taxi Task Team in 1995 as it acknowledged that violence is a problem, which needed investigation and a solution (National Taxi Task Team, 1996:12 and Molelekwa, 2008). 11

The above lack of mutual recognition of the policyproblem relates to one of the difficulties during the policyprocess: what is perceived as a problem by one person might not be regarded as a problem by another (Anderson, 2006:83). In addition, it implies that policyissues such as accidents, unroadworthy vehicles and minibus taxi violence do not just happen and are often "in the eye of the beholder". The identification of the policyproblem within the minibus taxi industry was thus contingent on who perceived an issue as a problem, when did they decide this and consequently how the problem was defined. Despite the lack of complete consensus at the policyproblem identification stage, the government in true statist fashion proceeded with the recapitalisation policyprocess.

11 Molelekwa is the head of communications at Santaco. 


\subsection{Forwarding the minibus taxi problems onto the policyagenda}

Following the identification of the policyproblem, the government should forward this perceived problem onto the policyagenda. However, not all policyproblems make it onto the policyagenda. To get onto the policyagenda, a problem must be converted into an issue that the government actually responds to (Starling, 1988:13; Dunn, 2004:45; and Fourie, 2004:12). Keeping this in mind, policyagenda setting can be defined as the different ways policyproblems can get onto the policyagenda, thus receiving the necessary and adequate attention of the policymakers. Sharskansky (2002:19-20) and Fox and Bayat (2006:53) for their part refer simply to policyagenda setting as the activity that places public policyproblems on the public policymaking agenda. Furthermore, to have a chance to be acted upon, a problem should be moved to the institutional policyagenda where policyproblems receive formal attention by the government (Anderson, 2006:87-88). It refers to government action in the form of resources, legislation and time-frames. The recapitalisation policy fits into institutional policyagenda setting as it requires resources (e.g. financial, human, and logistical), legislation (see above) and the constant attention of the government. It also has specific time-frames (i.e. 2005-2012) for its ultimate implementation, as pre-determined by the government.

Different role players are involved in the process of forwarding a policyproblem onto the policyagenda. Parsons (1997:128-129), Theodoulou and Kofinis (2004:69-73) and Booysen (2006:737-739) observe that policy agenda setting is facilitated by large sections of society, including the mass media, lobbyists and other interest groups as well as the Head of State (i.e. the president in South Africa's case). In addition, individual members of parliament, agency representatives and citizens who forward policyproblems onto the policyagenda also act as so-called policyentrepreneurs in the policyagenda setting process (Dye, 2005:40). As regards the TRP, however, it must be noted that, as the relevant role players in the minibus taxi industry never officially acknowledged that a problem exists in terms of accidents and unroadworthy vehicles (see above), their demands did not play a significant role in forwarding these problems onto the policyagenda as they did not establish the items on the policyagenda since they did not bring it into the policyrealm in the first place. This latter again highlights the statist conduct of the government in the recapitalisation policyprocess. 
On the other hand, agreeing that minibus taxi violence is indeed a problem did not imply that these role players participated in pushing it onto the policyagenda. To the contrary, a number of these role players (e.g. Top Six) have complained that they have not been included in the recapitalisation policyprocess (Headbush, 1999:7). Therefore, it is clear that when the government identified partially by itself what the problem was and proceeded with the recapitalisation policyprocess, it was, in line with the government's statist approach, a foregone conclusion that this problem would reach the government's policyagenda.

In an attempt to prevent a problem from attaining agenda status societal role players (e.g. those within the minibus taxi industry) may utilise a range of strategies. It is important to note that individuals or groups (e.g. role players within the minibus taxi industry) within society preventing certain policyproblems from attaining agenda status could also influence the policyagenda. These so-called anti-agenda setters may utilise a range of strategies to prevent a problem from reaching the policyagenda. These strategies may include a denial by anti-agenda setters that a problem exists and they might reason that the perceived policyproblem is inappropriate for government action and could be adequately dealt with by non-governmental means (Anderson, 2006:95-96). As regards the recapitalisation policy, role players (e.g. taxi associations, owners, and drivers) attempted in various ways to prevent the problem as identified by the government from reaching the policyagenda. For instance, bearing in mind the issue of unroadworthy vehicles and accidents as policyproblems, the role players in the minibus taxi industry protested that there was no problem with their vehicles. Therefore, they argued that they do not need, want or require the government's intervention - the recapitalisation policy (Raboroko, 1999:3; Headbush, 1999:7; Sebolao, 1999:1; and Anon., 1999:9).

The industry also argued that it was improper for the government to respond to the perceived policyproblem. These problems, they believed, could be addressed successfully by non-governmental entities (i.e. themselves). They were convinced that if a (policy) problem does exist, that only they are competent to address such a problem, as they presumably understand the industry best and consequently know best what the industry needs. Employing these tactics, the role players in the South African minibus taxi industry aimed to ensure that the problem as identified by the government lost its agenda status and consequently left the policyarena. However, notwithstanding all these attempts the government went 
on to pursue the recapitalisation policy. The problem therefore did not lose its agenda status. This again exemplifies the government's statist approach as it highlights the one-sided preservation of the agenda status of the perceived policyproblem within the minibus taxi industry.

\subsection{Formulating the taxi recapitalisation policy}

Subsequent to both identifying the policyproblem and forwarding it onto the policyagenda, the government proceeded to formulate the recapitalisation policy. As stated above, the government first formulated the original recapitalisation policy in 1999, followed by the revised version of the policy in 2004 together with various official role players (i.e. government departments, Santaco, and the motor industry).

In addition to the government, the public should also have the opportunity to be part of the policyformulation process. The South African Constitution stipulates in section 195 (1e), "the public must be encouraged to participate in policy-making" and the general principle is that this is facilitated through public hearings. However, in the formulation of both the original and revised recapitalisation policy no public hearings to ensure public participation have been held. This was confirmed by the Gauteng Deputy Director for Special Projects (Steeneveldt, 2008):

There were no official public hearings specifically for the recapitalisation policy. What we did have was meetings with the leadership of Santaco. The idea was that they should go back to their members and inform them. One should admit that the government should have approached this differently because this is the reason why the taxi owners, drivers, taxi washers and taxi rank marshals are still ill-informed about the recapitalisation policy. To sum it up; we have communicated, but not enough. Meaning we did involve the taxi leadership, which is good, but we should have also involved the afore-mentioned role players. 12

12 Interactions with four other respondents supported this observation, including the Director for Policy and Research at the Gauteng Department of Transport, Modise (2008) who noted, "I am not aware of any public hearings [for the recapitalisation policy]", and the head of communications at Santaco (Molelekwa, 2008). The other two respondents are high ranking officials at the National Department of Transport in Pretoria and requested that their identity and work designation remain anonymous, also refusing the usage of pseudonyms (They are referred to as Donna and Ethel (Anon., 2008a; 2008b) in 
The above clearly typifies the statist approach of the government in its formulation of the recapitalisation policy, as it failed to consider the interests and needs of the official (i.e. taxi owners) and/or unofficial role players (i.e. taxi drivers, vehicle cleaners, rank marshals, fare collectors, and commuters) of the recapitalisation policy, which were identified earlier. When the government official (Steeneveldt) mentions role players he is clearly only speaking about the government and Santaco (which was established with the assistance of the government), to the exclusion of all the relevant role players in the South African minibus taxi industry. This illustrates the marginalisation of these relevant role players and therefore the statist nature of the formulation of the recapitalisation policy because the government failed to provide a platform (i.e. public hearings) for their concerns during this process.

Another example of how the government acted on its own surfaces if one focuses, for example, on the formulation of the revised recapitalisation policy. On the day that the government officially announced the revised recapitalisation policy in November 2004, Santaco (the self-chosen ally of the government) said, "Santaco do not know the contents of the memorandum [on the recapitalisation policy] but expected an announcement soon" (quoted in Cokayne, 2004:1). In fact, Santaco, and the rest of the minibus taxi industry for that matter, was unaware of a revision of the recapitalisation policy. For instance, in the same aforementioned source the deputy director-general of transport notes, "they [the government] would not disclose the content of the memorandum as it was private to cabinet ..." Stating that the information, which clearly entailed specifications on the then unknown revised recapitalisation policy, "was private to cabinet" clearly typifies an assembling of elites, which in turn underlines a statist approach in the formulation of the revised recapitalisation policy.

In relation to the proposed new taxi vehicles, the original recapitalisation policy stipulated that the new taxis should use diesel. The mandatory use of diesel in the new taxis evoked reactions from the minibus taxi industry. For instance, Top Six and Santaco argued that the diesel stipulation would increase the maintenance cost of the new taxis because diesel is more expensive than petrol (Misbach, 1999:2; Yeld, 1999:12; Hlengani, 2005:44; and Nzapheza,

the list of references). The former suggests that these officials are aware that the government did not follow the proper channels in its formulation of the recapitalisation policy. 
2005:2). However, despite these objections to the diesel stipulation in the original recapitalisation policy, the government in its formulation of the revised version of the policy exemplified a statist approach and single-handedly decided that diesel should still be compulsory for the new taxis. This demonstrates a complete inconsideration of the needs, demands and financial sustainability of the target population.

All the above-mentioned flaws identified in the formulation process of the recapitalisation policy reflect a discrepancy between the approach (i.e. institutional statist conduct) of the government, on the one hand, and the needs (e.g. socio-economic needs) of both the official and unofficial target population of the policy, on the other hand. As noted earlier, all policies transpire within a policy environment and the government is greatly influenced by this environment since it limits as well as directs what they can or cannot do. Clearly indicative of its statist tactics, the government did not always take into consideration the socio-economic environment in its formulation of especially the original recapitalisation policy. For instance, as regards the specifications for the door of the original recapitalised new taxis, the government had specified that the door should be an electronic door (Parliamentary Monitoring Group, 2004b). Insisting that these vehicles should have an electronic door indicates that the government had lost sight of the fact that having an electronic door would increase the retail prices of the new taxis. Another example of how the formulators of the original recapitalisation policy ignored the socio-economic environment of the policy was the stipulation that all the new vehicles should be fitted with space for commuters who use wheelchairs. Initial calculations by the Department of Trade and Industry suggested that the inclusion of a wheelchair might add approximately R15 000 to the retail price of each vehicle, making the vehicle unaffordable to taxi owners. 13

Another example of the government's statist conduct in its formulation of the recapitalisation policy and its ignorance of the socio-

13 The inclusion of space for a wheelchair and most probably a higher purchase price for the new taxis led to dissatisfaction among various role players in the minibus taxi industry. Santaco, for instance, responded by stating that they do sympathise with, and acknowledge the constitutional right of people suffering from physical disabilities, to be treated equally. "However, these rights must be balanced against the rights of [other] commuters to [pay] the lowest possible fare" (Santaco, 2004:3). 
economic policy environment in which the policy occurs relates to the scrapping allowance of R50 000 payable to taxi owners in exchange for their old taxis. An alarming aspect of the scrapping allowance in the formulation of the TRP is that the amount was calculated even before the safety specifications for the new taxis were published in the Government Gazette. 14 The government simply ignored the potential price increase of the new taxis due to the safety regulations and acted in a one-sided manner. This conclusion can be based on the fact that the regulations were concluded only at the end of August 2005, while the scrapping allowance had already been finalised at the end of October 2004. At the time Top Six was indignant about the proposed R50 000 scrapping allowance to be awarded to taxi operators. Its former public relations officer, the late Rapodile (2005), voiced the association's biggest concern as regards the scrapping allowance: "How can you establish a scrapping allowance of R50 000 if you do not even know the expected retail price of the new taxis?"

The last aspect stressing the government's statist approach in its formulation of the recapitalisation policy relates to the government legitimising the policy by putting certain legal obligations on its target population. For example, taxi owners are required to obtain operating licences in order to operate in the industry and to qualify for the above-mentioned scrapping allowance. The policy is also universal as it is applicable to everyone within the minibus taxi industry. In addition, the government monopolises coercion to the recapitalisation policy by those within the industry because it is the sole institution that can lawfully indict those within the industry who do not comply with the policy.

14 The new taxis are and should be fitted with seatbelts for all the passengers and a Type 2 Braking System, while operating on commercially rated tyres of a specific size (in this case the size is 185R or 195R). It should also have a metal weatherproof roof and at least one emergency exit. There are also quite a number of stipulations regarding the seats of the new taxis that relate, for example, to the height of the seat, the direction in which the seat should face, the fact that there should only be one passenger seat at the front, and so forth. In addition, the safety requirements stipulate that the new taxis should be white, have a yellow reflective side with rear markings, bearing the South African flag on both sides of the vehicle. In addition, the new taxis must have the applicable provincial coat of arms and route number on its front with the taxi owner's details on the side (SADT, 2007:29). 


\section{Conclusions}

This article was devoted to an overview of the formulation process of the taxi recapitalisation policy. The aim was to highlight how the government acted in a statist manner in its formulation of the policy because it directed the course of the formulation process by assembling its elites to formulate the recapitalisation policy in accordance with its interests - thus a top-down approach without adequate consultation. Institutional statism was helpful in revealing that the formulation of the recapitalisation policy is the product of (and revolved around) the government and its policy institutions with little opportunity for the role players (i.e. the taxi industry) to buy into the formulation of the policy. This then also explains why the industry has not willingly complied with the policy, since it has been excluded from the process.

In addition to all the flaws mentioned in the formulation of the recapitalisation policy, two overriding problems have become evident in the formulation of the policy: firstly, the lack of mutual agreement between the government and the minibus taxi industry on what the problem in the industry really is. The government identified a number of problems, including the violence in the industry, the number of minibus taxis involved in accidents, and the large number of unroadworthy vehicles that presumably exacerbate the accident rate. The industry, on the other hand, merely regarded the occurrence of violence as a problem. As have been emphasised, clarity on what the problem is, is important since this determines the actions that need to be taken to address the issue(s) (i.e. the policy to be introduced). The implication of this lack of mutual agreement in identifying the problem is that it is unlikely that the measures the government takes to address the problem (from its perspective) will be supported by the minibus taxi industry. Furthermore, the government will have problems in implementing such a policy. Without mutual recognition of the policyproblem, the recapitalisation policy was bound to face problems from its inception.

A second important problem with the recapitalisation policy is the fact that it has been formulated in a one-sided manner - thus, a very statist approach has been followed. The government did not offer a platform for public participation through public hearings or any other form of interaction with the most important role players such as the taxi-owners, taxi associations or the trade unions. Both the original and revised versions of the recapitalisation policy were drawn up without the participation and input of these role players in the industry. Had the government consulted these role players, it would 
have been made aware of the unviability of its policy and alternatives to its proposed measures could have emerged, and these could have been debated.

\section{List of references}

ANDERSON, J. 2006. Public policymaking: an introduction. 6th ed. Boston: Mifflin.

ANON. 1999. Put taxi plan on hold. Sowetan: 9, 23 Aug.

ANON. 2008a. Donna, official at the national Department of Transport, Pretoria. (Telephonic interview on 16 July 2008.)

ANON. 2008b. Ethel, official at the taxi division of the national Department of Transport, Pretoria. (Telephonic interview on 10 July 2008.)

BARRETT, J. 2003. Organising in the informal economy: a case study of the minibus taxi industry in South Africa. Geneva: International Labour Office.

BOOYSEN, S. 2006. Consolidation of coordination in the centre: trends in public policy-making in South Africa. Journal of public administration, 41(4):731-749.

COKAYNE, R. 2004. Decision on taxi recapitalisation imminent. The Star: 1, 4 Nov.

DE CONING, C. \& CLOETE, F. 2006. Theories and models for analysing public policy. (In Cloete, F., Wissink, H. \& De Coning, C., eds. Improving public policy: from theory to practice. 2 nd ed. Pretoria: Van Schaik. p. 27-61.)

DUGARD, J. 2001. Drive on: taxi wars in South Africa. (In Steinberg, J., ed. Crime wave: the South African underworld and its foes. Johannesburg: University of Witwatersrand Press. p. 129-149.)

DUNN, W. 2004. Public policy analysis: an introduction. 3rd ed. New Jersey: Prentice-Hall.

DYE, T. 2005. Understanding public policy. 11th ed. New Jersey: Prentice-Hall.

FOURIE, P. 2004. Public policy: theoretical exploration and synthesis. Politeia, 23(1):4-32.

FOX, W. \& BAYAT, S. 2006. Managing policy. (In Fox, W., Bayat, M. \& FERREIRA, I., eds. A guide to managing public policy. Cape Town: Juta. p. 47-62.)

HEADBUSH, B. 1999. Industry overhaul plan splits taxi associations. The Star: 7, 30 Jun.

HILL, M. 1980. Understanding social policy. Oxford: Blackwell.

HLENGANI, T. 2005. Final specs cause more mutterings. Financial mail: 44, 29 Jul.

JOHN, P. 2000. Analysing public policy. London: Continuum.

KHANGALE, N. 2003. Taxi protest looms over new vehicles. Sunday independent: 2, 27 Apr.

LARSEN, T., TAYLOR-GOOBY, P. \& KANANEN, J. 2006. New labour's policy style: a mix of policy approaches. Journal of social policy, 35(4):629-649.

MABUZA, E. 2003. Erwin downplays failure to sign taxi accord. Business day: 2, 9 Oct.

MARCH, J. \& OLSEN, J. 1997. Institutional perspectives on political institutions. (In Hill, M., ed. The policy process: a reader. London: Prentice-Hall. p. 126-154.) 
MISBACH, W. 1999. Government's diesel taxi proposal condemned. Sowetan: 2, 20 Dec.

MODISE. 2008. E-mail discussion on 8 September 2008.

MOLELEKWA, M. 2008. Personal interview on 15 September 2008.

MONTANA, L. 2005. Personal interview on 17 March 2005.

NATIONAL TAXI TASK TEAM. 1996. Final recommendations. Pretoria: Government Printer.

NZAPHEZA, V. 2005. Taxi body stalls over project. Citizen: 2, 18 Aug.

PALUMBO, D.J. \& CALISTA, D.J., eds. 1990. Opening up the black box: implementation and the policy process. London: Greenwood.

PARLIAMENTARY MONITORING GROUP. 2000. Briefing by Sataco. http://www.pmg.org.za/viewminute.php?id=4402 Date of access: $11 \mathrm{Dec}$. 2007.

PARLIAMENTARY MONITORING GROUP. 2004a. Future of public transport: discussion with Santaco and CSIR. http://www.pmg.org.za/viewminute. php?id=4326 Date of access: 18 Aug. 2004.

PARLIAMENTARY MONITORING GROUP. 2004b. Taxi recapitalisation: Santaco concerns and solutions. http://www.pmg.org.za/docs/2004/appendices/040813santaco.htm Date of access: 13 Aug. 2004.

PARLIAMENTARY MONITORING GROUP. 2006. Taxi recapitalisation: Santaco concerns and recommendations. http://www.pmg.org.za/docs/ 2006/060920santaco.htm Date of access: 20 Sept. 2006.

PARSONS, W. 1997. Public policy: an introduction to the theory and practice of policy analysis. Cheltenham: Elgar.

RABOROKO, J. 1999. Radical changes in transport. Sowetan: 3, 21 Jun.

RAPODILE, M. 2005. Personal interview on 22 March 2005.

ROUX, N. 2006. Policy design. (In Cloete, F., Wissink, H. \& De Coning, C., eds. Improving public policy: from theory to practice. 2nd ed. Pretoria: Van

SADT Schaik. p. 125-164.)

see SOUTH AFRICA. Department of Transport

SANTACO. 2004. Taxi recapitalisation: Santaco concerns and solutions. Pretoria: Santaco.

SEBOLAO, P. 1999. Taxi alliance urges government to halt recapitalisation. Business day: 1, 16 Aug.

SHARKANSKY, I. 2002. Politics and policymaking: in search of simplicity. London: Rienner.

SOUTH AFRICA. 1996. South African Constitution. Cape Town: Government Printer.

SOUTH AFRICA. 2000. National Land Transport Transition Act of 2000. Government gazette, 21493.

SOUTH AFRICA. 2006. National Land Transport Transition Act of 2006. Government gazette, 29763.

SOUTH AFRICA. 2008. National Land Transport Transition Bill of 2008. Government gazette, 30928.

SOUTH AFRICA. Department of transport. 1977. Road Transportation Act of 1977. Pretoria: Government Printer.

SOUTH AFRICA. Department of transport. 2007a. A walking policy for transport. http://www.transport.gov.za/comm-centre/sp/2007/sp0912.html Date of access: 12 Sept. 2007. 
SOUTH AFRICA. Department of transport. 2007b. National scholar transport policy. Pretoria: Government Printer.

SOUTH AFRICA. Department of transport. 2008. Taxi recapitalisation policy document. Pretoria: Government Printer.

STARLING, G. 1988. Strategies for policy making. Chicago: Dorsey.

STEENEVELDT. 2008. Personal interview on 20 August 2008.

THEODOULOU, S.Z. \& KOFINIS, C. 2004. The art of the game: understanding American public policy making. Belmont: Wadsworth.

TOP SIX. 2000. Document presented to the deputy president of Republic of South Africa, J.Z. Zuma. Pretoria.

YELD, J. 1999. Diesel taxis serious health threat. Cape argus: 12, 22 Dec.

\section{Key concepts:}

institutional statism

minibus taxi

policyformulation

public policy

taxi recapitalisation

\section{Kernbegrippe:}

beleidsformulering

institutialisme

minibus taxi

openbare beleid

taxiherkapitalisering 
